\title{
Duration of post-operative hypocortisolism predicts sustained remission after pituitary surgery for Cushing's disease
}

\author{
Prachi Bansal', Anurag Lila', Manjunath Goroshi', Swati Jadhav', Nilesh Lomte', \\ Kunal Thakkar', Atul Goel2 ${ }^{2}$ Abhidha Shah², Shilpa Sankhe³, Naina Goel', \\ Neelam Jaguste', Tushar Bandgar ${ }^{1}$ and Nalini Shah' \\ ${ }^{1}$ Department of Endocrinology, Seth G.S. Medical College and KEM Hospital, Mumbai, Maharashtra, India \\ 2Department of Neurosurgery, Seth G.S. Medical College and KEM Hospital, Mumbai, Maharashtra, India \\ ${ }^{3}$ Department of Radiology, Seth G.S. Medical College and KEM Hospital, Mumbai, Maharashtra, India \\ ${ }^{4}$ Department of Pathology, Seth G.S. Medical College and KEM Hospital, Mumbai, Maharashtra, India
}

Correspondence should be addressed to A Lila Email anuraglila@gmail.com

\begin{abstract}
Purpose: Transsphenoidal surgery (TSS) is the primary treatment modality for Cushing's disease (CD). However, the predictors of post-operative remission and recurrence remain debatable. Thus, we studied the post-operative remission and long-term recurrence rates, as well as their respective predictive factors.

Methods: A retrospective analysis of case records of $230 \mathrm{CD}$ patients who underwent primary microscopic TSS at our tertiary care referral centre between 1987 and 2015 was undertaken. Demographic features, pre- and post-operative hormonal values, MRI findings, histopathological features and follow-up data were recorded. Remission and recurrence rates as well as their respective predictive factors were studied.

Results: Overall, the post-operative remission rate was $65.6 \%$ (early remission $46 \%$; delayed remission $19.6 \%$ ), while the recurrence rate was $41 \%$ at mean follow-up of $74 \pm 61.1$ months (12-270 months). Significantly higher early remission rates were observed in patients with microadenoma vs macroadenoma $(51.7 \%$ vs $30.6 \%, P=0.005)$ and those with unequivocal vs equivocal MRI for microadenoma $(55.8 \%$ vs $38.5 \%$, $P=0.007)$. Patients with invasive macroadenoma had poorer ( $4.5 \%$ vs $45 \%, P=0.001)$ remission rates. Recurrence rates were higher in patients with delayed remission than those with early remission $(61.5 \%$ vs $30.8 \%, P=0.001)$. Duration of post-operative hypocortisolemia $\geq 13$ months predicted sustained remission with $100 \%$ specificity and $46.4 \%$ sensitivity. Recurrence could be detected significantly earlier (27.7 vs 69.2 months, $P<0.001)$ in patients with available serial follow-up biochemistry as compared to those with infrequent follow-up after remission.

Conclusion: In our study, remission and recurrence rates were similar to that of reported literature, but proportion of delayed remission was relatively higher. Negative/equivocal MRI findings and presence of macroadenoma, especially those with cavernous sinus invasion were predictors of poor remission rates. In addition to early remission, longer duration of post-operative hypocortisolism is an important predictor of sustained remission. Regular biochemical surveillance may help in identifying recurrence early.
\end{abstract}

Key Words

- Cushing's disease

- pituitary adenoma

- transspenoidal surgery

- remission

- post-operative hypocortisolism
Endocrine Connections (2017) 6, 625-636

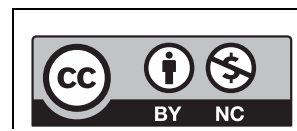

This work is licensed under a Creative Commons Attribution-NonCommercial 4.0 International License. 


\section{Introduction}

Cushing's disease (CD) is a state of cortisol excess, caused by an ACTH-secreting pituitary adenoma. Although a rare disease with an annual incidence of 1.5 patients/million (1), it is associated with significant morbidity and mortality (2). Transsphenoidal surgery (TSS) of pituitary adenoma is the primary treatment modality, with varying remission rates (52-96.6\%) reported across different centres (3). Various demographic, biochemical, radiological and histopathological features have been studied as predictors of remission following TSS. Amongst these, visualisation of adenoma on preoperative neuroradiography, tumour size, its invasiveness and histopathological confirmation of adenoma have been largely reported to be predictive of remission in various studies $(4,5,6)$.

Recurrence of CD following remission after TSS is a well-recognised phenomenon and is reported to be as high as $15-66 \%$ in various long-term studies (7), emphasising the need for long-term follow-up. Understanding the predictors of sustained remission might help us to better strategise follow-up care of patients. Amongst the various factors studied, the presence of early postoperative hypocortisolism and lack of response to $\mathrm{CRH} /$ desmopressin stimulation tests have been reported to be positive predictors of sustained remission $(8,9,10)$.

In the current study, we report long-term follow-up of CD patients after first microscopic TSS. We aim to study the post-operative remission and long-term recurrence rates, as well as their respective predictive factors.

\section{Subjects and methods}

A retrospective analysis of case records of CD patients $(n=236)$ who underwent microscopic TSS as first line management at our tertiary care referral centre between 1987 and 2015 was undertaken. Institutional ethics committee approval with a waiver of informed consent was obtained for this retrospective analysis. Excluding 6 patients for whom early post-operative hormonal values were not available, data of $230 \mathrm{CD}$ patients were analysed.

Baseline demographic features, pre- and post-operative hormonal values, MRI findings and histopathological features were recorded. Endogenous hypercortisolism was defined as serum cortisol $>1.8 \mu \mathrm{g} / \mathrm{dL}$ after standard two days low-dose dexamethasone suppression test $(0.5 \mathrm{mg}$ dexamethasone every $6 \mathrm{~h}$ for 2 consecutive days) \pm sleeping midnight serum cortisol $>5 \mu \mathrm{g} / \mathrm{dL}$ (11). ACTH dependency was confirmed by basal plasma ACTH $>10 \mathrm{pg} / \mathrm{mL}$.
After biochemical confirmation, patients underwent dynamic contrast enhanced MRI (1.5T) pituitary. Since 2009, volume-interpolated 3D spoiled gradient-echo (VI-SGE) MR sequences have been used additionally (12). For patients with negative/equivocal MRI findings, inferior petrosal sinus sampling (IPSS) was done to confirm the central source of ACTH secretion (CRH-stimulated central: peripheral ACTH ratio $>3$; unstimulated central: peripheral ACTH ratio >2) (13). Patients with negative/ equivocal MRI findings or adenomas $\leq 10 \mathrm{~mm}$ were classified as microadenomas, whereas adenomas $>10 \mathrm{~mm}$ were categorised as macroadenomas. For macroadenomas, the Knosp classification system was applied, and grades 3 and 4 lesions were categorised as invasive (14).

TSS was performed successively by two experienced neurosurgeons, one prior to 1999 , and other from that year on. Selective transsphenoidal adenomectomy was the primary surgical approach followed by both the surgeons. Peri-operatively, patients received intravenous hydrocortisone $(50 \mathrm{mg} 6 \mathrm{~h}$ ) on the day of surgery, which was replaced with oral prednisolone tablet $(5 \mathrm{mg}$ once a day in morning) on second and third postoperative day. Morning 08:00h serum cortisol \pm plasma ACTH was documented in first post-operative week (usually fifth day, $48 \mathrm{~h}$ after last prednisolone dose). Patients having 08:00h serum cortisol $<5 \mu \mathrm{g} / \mathrm{dL}$ were considered hypocortisolemic, and were continued steroid replacement (oral prednisolone $5 \mathrm{mg}$ once a day). Patients with serum cortisol $\geq 5 \mu \mathrm{g} / \mathrm{dL}$ were given steroid replacement, only if they had symptoms attributable to hypocortisolism. All patients were advised regarding the need of stress dosage of steroids during periods of intercurrent illnesses (if any). Initial post-operative follow-up visits were on a quarterly basis. On follow-up, 08:00 h serum cortisol was documented, and if it was $\geq 5 \mu \mathrm{g} / \mathrm{dL}$, $1 \mathrm{mg}$ overnight dexamethasone suppression test (ODST) was performed. Overall, patients were categorised into three groups - early remission, delayed remission and persistent disease. Early remission was defined as achieving early post-operative (usually fifth day) hypocortisolism (08:00h serum cortisol $<5 \mu \mathrm{g} / \mathrm{dL}$ ) (7). Delayed remission was defined as early post-operative 08:00 h serum cortisol $\geq 5 \mu \mathrm{g} / \mathrm{dL}$, but achieving hypocortisolism (08:00 h serum cortisol $<5 \mu \mathrm{g} / \mathrm{dL}$ ) or eucortisolism (08:00 h serum cortisol $\geq 5 \mu \mathrm{g} / \mathrm{dL}$ ) and ODST serum cortisol $\leq 1.8 \mu \mathrm{g} / \mathrm{dL}$ ) at initial follow-up visit (upto 6 months). Persistent disease was defined as early post-operative serum cortisol $\geq 5 \mu \mathrm{g} / \mathrm{dL}$ with documented hypercortisolism (ODST serum cortisol 
$>1.8 \mu \mathrm{g} / \mathrm{dL}$ ) at initial follow-up visits. Patients in the remission group were followed up 6-12 monthly. For the analysis of disease recurrence, patients having a minimum follow-up of 12 months post surgery were included. The hormonal evaluation at follow-up visits included 08:00h serum cortisol, ODST cortisol (done if 08:00h serum cortisol was $\geq 5 \mu \mathrm{g} / \mathrm{dL}$ ), free thyroxine $\left(\mathrm{FT}_{4}\right)$ and thyrotropin (TSH). Another hormonal evaluation for growth, puberty and sexual function was done if clinically indicated. Patients having 08:00 h serum cortisol $<5 \mu \mathrm{g} / \mathrm{dL}$ were considered hypocortisolemic and were continued on steroid replacement (oral prednisolone $2.5-5 \mathrm{mg}$ once a day). ACTH stimulation test was not performed due to non-availability of short-acting preparation of ACTH in India. Recurrence of the disease was defined as ODST serum cortisol $>1.8 \mu \mathrm{g} / \mathrm{dL}$ in patients with prior remission.

\section{Assays}

Hormonalevaluationwasradioimmunoassaybasedinitially, and was later (after 1999) shifted to chemiluminescent assay. Cortisol was measured by a solid-phase competitive chemiluminescent enzyme immunoassay (Siemens Healthcare) with an analytical sensitivity of $0.2 \mu \mathrm{g} / \mathrm{dL}$. The intra- and interassay coefficients of variability (CVs) of the cortisol assay were $6.9 \%$ and $7.3 \%$, respectively. ACTH was measured by a solid-phase, two-site sequential chemiluminescent assay (Siemens Healthcare). The intraand interassay CVs were $9.6 \%$ and $8.8 \%$, respectively, and the sensitivity was $0.5 \mathrm{pg} / \mathrm{mL}$.

\section{Statistical analysis}

Qualitative data were represented in the form of frequency and percentage. Association between qualitative variables was assessed by the chi-square test with continuity correction and Fisher's exact test when required. Quantitative data were represented using mean \pm s.D. (standard deviation). Analysis of quantitative data between the two groups was carried out using unpaired t-test/Mann-Whitney test, while one-way ANOVA test was used for comparing $>2$ groups. Analysis of recurrence on longitudinal evaluation was carried out by the KaplanMeier method. Receiver-operator characteristic (ROC) analysis was performed to find the optimal cut-off point for the duration of hypocortisolism in predicting recurrence in patients having remission. For all statistical tests, $P<0.05$ was considered significant. Statistical analysis was performed using software IBM SPSS Statistics, version 23.0.

\section{Results}

\section{Remission}

In our cohort of $230 \mathrm{CD}$ patients, the overall remission rate after first TSS was $65.6 \%$ (early remission rate: $46 \%, n=106$; delayed remission rate: $19.6 \%, n=45)$, while $79(34.4 \%)$ patients had persistent hypercortisolism. As shown in Table 1, a comparison of clinical, biochemical, radiological and histopathological characteristics of the three subgroups (patients with early remission, delayed remission and persistent hypercortisolism) revealed no significant differences except for the radiological characteristics. Patients with microadenomas had significantly higher (51.7\% vs $30.6 \%, P=0.005)$ rates of early remission, and lesser $(28.6 \%$ vs $50 \%, P=0.005)$ rates of persistent disease, as compared to patients with macroadenoma. However, the proportion of patients achieving delayed remission was similar (19.7\% vs $19.4 \%, P=0.124)$ amongst patients with microadenoma and macroadenoma. On the subanalysis of patients with macroadenoma, patients with invasive tumours had significantly lower (4.5\% vs $45 \%$, $P<0.001)$ rates of early remission, and had higher $(77.3 \%$ vs $35 \%, P<0.001$ ) rates of persistent disease, as compared to patients with non-invasive tumours. On the subanalysis of patients with microadenoma, patients with unequivocal visualisation of adenoma on MRI had higher rates of early remission $(55.8 \%$ vs $38.5 \%, P=0.007)$, and lower rates of persistent disease $(23.3 \%$ vs $46.1 \%$, $P=0.007)$ as compared to those with negative/equivocal findings. Amongst patients with microadenoma, early remission (53.1\% vs $43.5 \%, P=0.683)$, delayed remission (19.3\% vs $21.7 \%, P=0.683$ ) and disease persistence rates (27.6\% vs $34.8 \%, P=0.683$ ) were similar in patients with histopathologically proven adenoma as compared to those with negative histopathological findings.

\section{Recurrence}

Of 151 patients achieving remission, long-term follow-up ( $\geq 12$ months post-surgery) data were available for 117 patients (91 with microadenoma, 26 with macroadenoma), who were included in the analysis for disease recurrence. Out of these 117 patients, 78 patients had early postoperative remission, while 39 patients had delayed remission. At mean follow-up of $74 \pm 61.1$ months (range: 12-270 months) post-surgery, the overall recurrence rate was $41 \%(48 / 117)$, and mean time to recurrence was $37.2 \pm 27.8$ (8-96) months. The Kaplan-Meier analysis for recurrence-free survival is shown in Fig. 1.

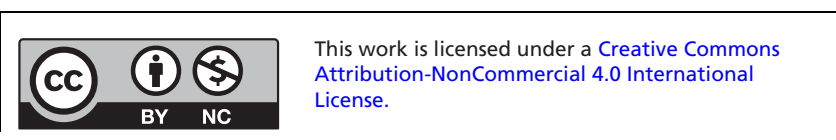


Table 1 Predictors of remission for Cushing's disease following first transsphenoidal adenomectomy.

\begin{tabular}{l}
\hline \\
\hline Female:male ratio \\
Age at diagnosis in years (mean \pm S.D. (range)) \\
Duration of symptoms in years (mean \pm S.D. (range)) \\
Preoperative laboratory values (mean \pm S.D.) \\
$08: 00$ h serum cortisol (ug/dL) \\
Plasma ACTH (pg/mL) \\
Sleeping midnight serum cortisol* (ug/dL) \\
LDDS cortisol (ug/dL) \\
Microadenoma ( $n=168)$ \\
Macroadenoma ( $n=62)$ \\
Macroadenomas ( $n=62)$ \\
With CSI ( $n=22)$ \\
Without CSI $(n=40)$ \\
Microadenomas \\
Equivocal (IPPS proven CD) $(n=39)$ \\
Unequivocal ( $n=129)$ \\
Microadenomas \\
Histopathologically \\
Positive ( $n=145)$ \\
Negative ( $n=23$ )
\end{tabular}

27.

\begin{tabular}{c}
$\begin{array}{c}\text { Early remission } \\
(n=106)\end{array}$ \\
\hline $3.8: 1(84 / 22)$ \\
$27.3 \pm 10.9(7-60)$ \\
$26.8 \pm 22.4(1-120)$
\end{tabular}

\begin{tabular}{c}
$\begin{array}{c}\text { Delayed remission } \\
(n=45)\end{array}$ \\
\hline $2: 1(30 / 15)$ \\
$24.9 \pm 10.5(10-55)$ \\
$24.2 \pm 28(3-144)$
\end{tabular}

\begin{tabular}{|c|c|}
\hline $\begin{array}{c}\text { Persistent disease } \\
\qquad(n=79)\end{array}$ & $P$ value \\
\hline $2.16(54 / 25)$ & 0.144 \\
\hline $27.3 \pm 10.8(10-53)$ & 0.406 \\
\hline $34.6 \pm 32.4(3-144)$ & 0.071 \\
\hline $30.5 \pm 12.1$ & 0.342 \\
\hline $89 \pm 61.4$ & 0.864 \\
\hline $25 \pm 14.9$ & 0.083 \\
\hline $21.3 \pm 11.8$ & 0.528 \\
\hline $\begin{array}{c}48 / 168(28.6 \%) \\
31 / 62(50 \%)\end{array}$ & 0.005 ** \\
\hline $\begin{array}{l}17 / 22(77.3 \%) \\
14 / 40(35 \%)\end{array}$ & $<0.001$ ** \\
\hline $\begin{array}{r}18 / 39(46.1 \%) \\
30 / 129(23.3 \%)\end{array}$ & $0.007 * *$ \\
\hline $\begin{array}{r}40 / 145(27.6 \%) \\
08 / 23(34.8 \%)\end{array}$ & 0.683 \\
\hline
\end{tabular}

*Data for sleeping midnight serum cortisol were available in 146 patients; **P value significant only between early remission and persistent disease on post hoc analysis.

CSI, cavernous sinus invasion; IPSS, inferior petrosal sinus sampling; LDDS, low-dose dexamethasone suppression.

There was no significant difference in either recurrence rate $(38.46 \%$ vs $50 \%, P=0.367)$ or mean time to recurrence ( $36.9 \pm 24.4$ vs $38.08 \pm 18.2$ months, $P=0.88$ ) when patients with microadenoma were compared to those with macroadenoma. The patients with early

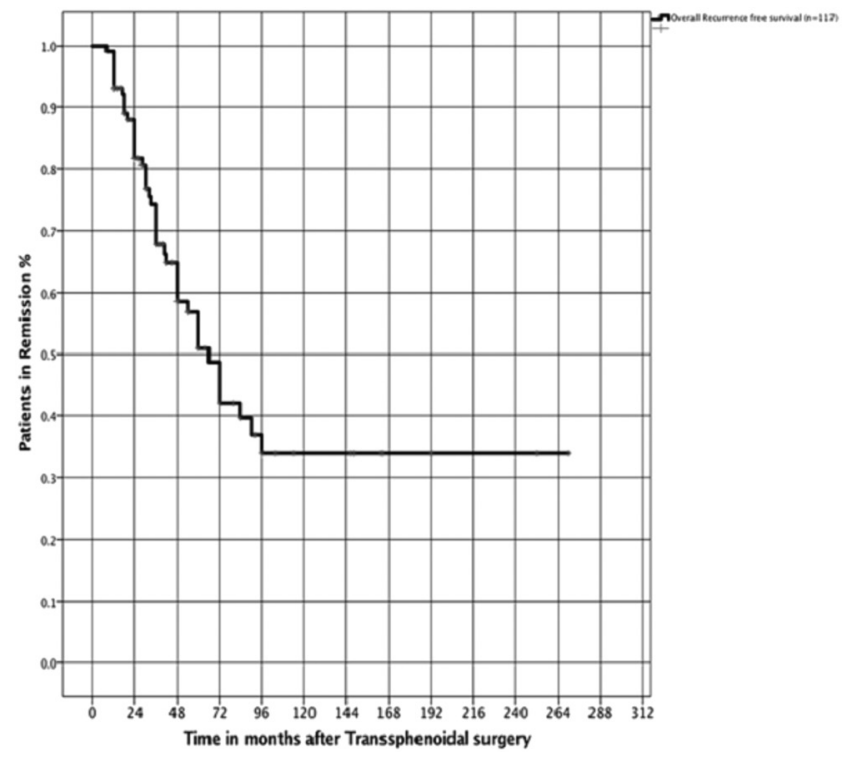

Figure 1

Kaplan-Meier curve showing recurrence-free survival of Cushing's disease patients who are in remission after transsphenoidal adenomectomy. remission had a significantly lower recurrence rate $(30.8 \%$ vs $61.5 \%, P=0.001)$, with a trend towards later time to recurrence (mean time to recurrence of $41.9 \pm 26.5$ months vs $32.7 \pm 17.7$ months, $P=0.176)$ as compared to those having delayed remission.

For analysing predictors of recurrence in each of the early and delayed remission groups, different demographic, biochemical, radiological and histopathological characteristics of patients with recurrence were compared to those having sustained remission (Table 2). Of these, some of the post-operative biochemical characteristics were found to be significantly different amongst these sub-groups.

Overall, there was no significant difference in early post-operative (day 5) serum cortisol levels between patients with recurrence vs those with sustained remission in both early and delayed remission groups. However, in the early remission group, a trend towards lower recurrence rate was observed in patients with early post-operative serum cortisol levels $<1.8 \mu \mathrm{g} / \mathrm{dL}$ vs those with levels between 1.8 and $4.9 \mu \mathrm{g} / \mathrm{dL}(17.02 \%$ vs $36.36 \%$, $P=0.124)$.

For calculation of duration of post-operative hypocortisolism/eucortisolism, the analysis was restricted to cohort of patients where the available longitudinal biochemical data could allow for the interpretation of
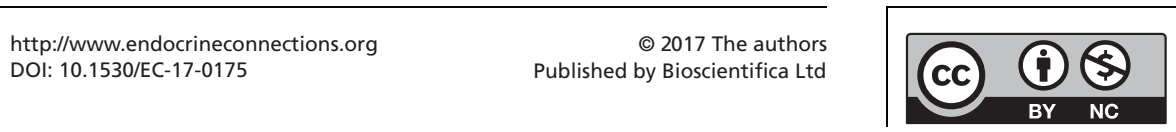

This work is licensed under a Creative Commons Attribution-NonCommercial 4.0 International License. 
Table 2 Predictors of recurrence in patients achieving remission after transsphenoidal adenomectomy.

\begin{tabular}{|c|c|c|c|}
\hline \multicolumn{4}{|c|}{ Early remission group $(n=78)$} \\
\hline & Recurrence group $(n=24)$ & Sustained remission group $(n=54)$ & $P$ value \\
\hline Female:male ratio & $3: 1(18 / 6)$ & $5: 1(45 / 9)$ & 0.534 \\
\hline Age at diagnosis in years (mean \pm S.D.) & $25.2 \pm 9.9$ & $27.1 \pm 11.4$ & 0.504 \\
\hline LDDS cortisol (ug/dL) (mean \pm s.D.) & $20.2 \pm 14.1$ & $19.7 \pm 11.5$ & $0.897 *$ \\
\hline \multicolumn{4}{|l|}{ Tumour size at baseline } \\
\hline Microadenoma, $(n=62)$ & $18 / 62(29 \%)$ & $44 / 62(71 \%)$ & 0.552 \\
\hline Macroadenoma, $(n=16)$ & $06 / 16(37.5 \%)$ & $10 / 16(62.5 \%)$ & \\
\hline \multicolumn{4}{|l|}{ Macroadenomas $(n=16)$} \\
\hline With CSI $(n=1)$ & 00/01 & 01/01 (100\%) & 1.00 \\
\hline Without CSI $(n=15)$ & $06 / 15(40 \%)$ & $09 / 15(60 \%)$ & \\
\hline \multicolumn{4}{|l|}{ Microadenomas $(n=62)$} \\
\hline Equivocal (IPPS proven CD) $(n=07)$ & 04/07 (57.1\%) & 03/07 (42.9\%) & 0.179 \\
\hline Unequivocal $(n=55)$ & $14 / 55(25.5 \%)$ & $41 / 55(74.5 \%)$ & \\
\hline \multicolumn{4}{|l|}{ Microadenomas $(n=62)$} \\
\hline Histopathology positive $(n=53)$ & $15 / 53(28.3 \%)$ & $38 / 53(71.7 \%)$ & 0.711 \\
\hline Histopathology negative $(n=9)$ & 03/09 (33.3\%) & $06 / 09(66.7 \%)$ & \\
\hline Post-surgery day 5 cortisol ( $\mu \mathrm{g} / \mathrm{dL})$ (mean \pm s.D.) & $1.9 \pm 1.3$ & $1.5 \pm 0.9$ & 0.222 \\
\hline Duration of hypocortisolism in months (mean \pm s.D. (range)) & $5.8 \pm 3.2(2-12)(n=15)$ & $18.5 \pm 16.9(2-92)(n=51)$ & $<0.001$ \\
\hline Duration of eucortisolism in months (mean \pm s.D. (range)) & $29.2 \pm 21.7(9-84)(n=14)$ & $50.1 \pm 60.1(2-250)(n=36)$ & 0.076 \\
\hline \multicolumn{4}{|c|}{ Delayed remission group $(n=39)$} \\
\hline & Recurrence group $(n=24)$ & Sustained remission group $(n=15)$ & $P$ value \\
\hline Female:male ratio & $1.67(15 / 9)$ & $1.5(9 / 6)$ & 1.000 \\
\hline Age at diagnosis in years (mean \pm S.D.) & $23.1 \pm 8.5$ & $27.7 \pm 13.8$ & 0.210 \\
\hline LDDS cortisol (ug/dL) (mean \pm s.D.) & $22.9 \pm 14.9$ & $21.8 \pm 16.5$ & $0.850 *$ \\
\hline \multicolumn{4}{|l|}{ Tumour size at baseline } \\
\hline Microadenoma, $(n=29)$ & $17 / 29(58.6 \%)$ & $12 / 29(41.4 \%)$ & 0.711 \\
\hline Macroadenoma, $(n=10)$ & $07 / 10(70 \%)$ & $03 / 10(30 \%)$ & \\
\hline \multicolumn{4}{|l|}{ Macroadenomas $(n=10)$} \\
\hline With CSI $(n=04)$ & $03 / 04(75 \%)$ & $01 / 04(25 \%)$ & 1.00 \\
\hline Without CSI $(n=06)$ & 04/06 (66.7\%) & 02/06 (33.3\%) & \\
\hline \multicolumn{4}{|l|}{ Microadenomas $(n=29)$} \\
\hline Equivocal (IPPS proven CD) $(n=05)$ & $03 / 05(60 \%)$ & $02 / 05(40 \%)$ & 1.00 \\
\hline Unequivocal $(n=24)$ & $14 / 24(58.3 \%)$ & $10 / 24(41.7 \%)$ & \\
\hline \multicolumn{4}{|l|}{ Microadenomas $(n=29)$} \\
\hline Histopathology positive $(n=25)$ & $14 / 25(56 \%)$ & $11 / 25(44 \%)$ & 0.622 \\
\hline Histopathology negative $(n=4)$ & $03 / 04(75 \%)$ & $01 / 04(25 \%)$ & \\
\hline Post-surgery day 5 cortisol ( $\mu \mathrm{g} / \mathrm{dL})$ (mean \pm s.D. (range)) & $16 \pm 11.5(5.1-50)$ & $15.4 \pm 10.6(5.09-38)$ & 0.873 \\
\hline Duration of hypocortisolism (months) (mean \pm s.D. (range)) & $6 \pm 2.6(3-9)(n=6)$ & $30 \pm 16.9(12-48)(n=5)$ & 0.044 \\
\hline Duration of eucortisolism (months) (mean \pm s.D. (range)) & $25.4 \pm 12.5(5-48)(n=18)$ & $48.6 \pm 51(12-192)(n=12)$ & 0.337 \\
\hline
\end{tabular}

*Other preoperative hormonal tests (08:00 h serum cortisol, sleeping midnight serum cortisol) were also not significantly different.

CSI, cavernous sinus invasion; IPSS, inferior petrosal sinus sampling; LDDS, low-dose dexamethasone suppression.

approximate time points of transition in cortisol status. Mean duration of post-operative hypocortisolism was shorter amongst patients who recurred vs patients having sustained remission (early remission cohort: $5.8 \pm 3.2$ months in the recurred group vs $18.5 \pm 16.9$ months in the sustained remission group, $P<0.001$; delayed remission cohort: $6 \pm 2.6$ months in the recurred group vs $30 \pm 16.9$ months in the sustained remission group, $P=0.044$ ) (Table 2). Post-operative hypocortisolism of $\geq 7$ months duration predicted sustained remission with $72.5 \%$ sensitivity and $76.2 \%$ specificity (ROC analysis, Fig. 2). At a cut-off of $\geq 13$ months, specificity of predicting

http://www.endocrineconnections.org DOI: 10.1530/EC-17-0175

17 The authors Published by Bioscientifica Ltd sustained remission increased to $100 \%$ (with sensitivity of $46.4 \%$ ). Duration of post-operative eucortisolism was apparently shorter (early remission: $29.2 \pm 21.7$ months vs $50.1 \pm 60.1$ months, $P=0.076$; delayed remission: $25.4 \pm 12.5$ months vs $48.6 \pm 51$ months, $P=0.337$ ) amongst patients who recurred vs patients with sustained remission.

Time to recurrence As depicted in Fig. 1, in overall cohort, there was a constant decline (without clustering) in the percentage of patients with recurrence-free survival till 96 months of follow-up, after which the curve

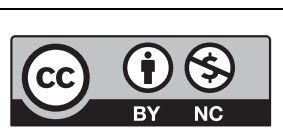

This work is licensed under a Creative Commons Attribution-NonCommercial 4.0 International License. 


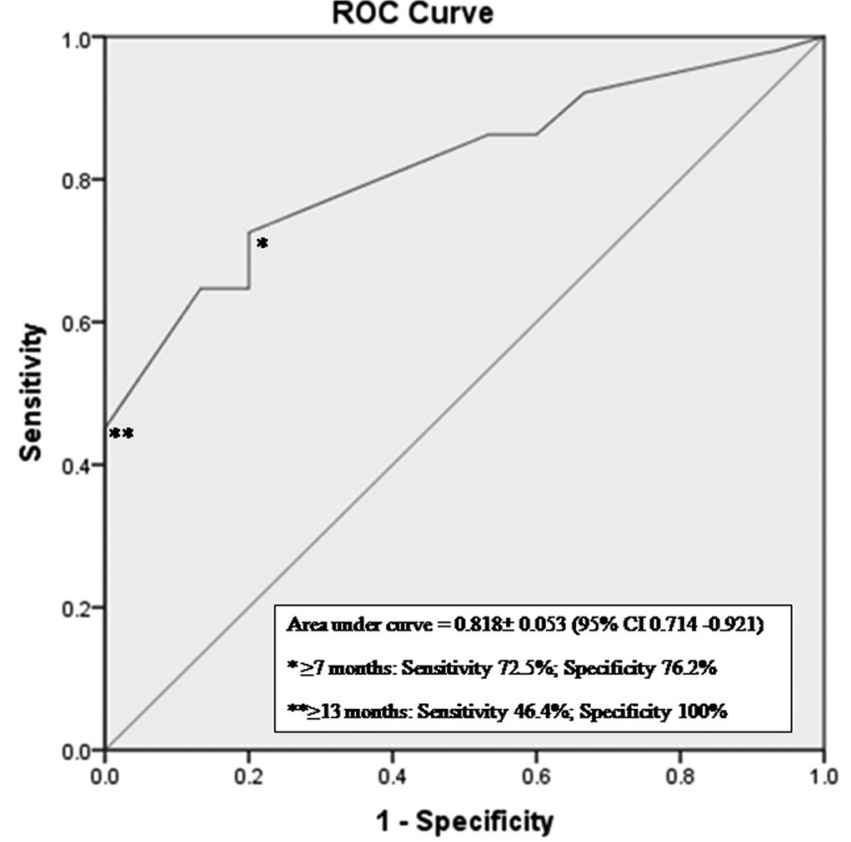

Figure 2

Receiver-operator characteristic curve showing duration of hypocortisolism as a predictor of recurrence.

plateaus. Out of 48 patients with recurrence, serial data on biochemical evaluation at regular follow-up visits (at least once in two years) were available for 33 patients, while in remaining 15 patients, follow-up was less frequent with no intervening biochemistry available to analyse precise time of recurrence. The mean time to recurrence for the former group of 33 patients was 27.7 months (median: 26 months, range: $8-60$ months), with $84.38 \%$ patients recurring within first 3 years after surgery and rest (15.62\%) recurring in next 2 years. No recurrences were observed after 5 years of surgery in this group. For the latter group of 15 patients with intermittent and infrequent followup, time to recurrence was significantly longer (mean: 69.2 months; median: 72 months; range: 48-96 months) as compared to the former group of 33 patients $(P<0.001)$.

Site of recurrence Amongst the patients with recurrence, both pre-surgical and follow-up pituitary MRI scans (at the time of disease recurrence) were available for comparison in 40 patients (macroadenoma $(n=11)$, microadenoma $(n=29,22$ with unequivocal and 7 with equivocal findings)). Out of 11 patients with macroadenomas, follow-up scans at the time of recurrence revealed adenoma in the same sellar location (as baseline scan) in 10 patients, while it was not visualised in one patient. In patients with unequivocal visualisation of microadenoma, recurrent adenoma was found in the same sellar location (as seen in baseline scan) in 50\% $(11 / 22)$ of patients while in the remaining patients, it was not visualised clearly.

\section{Discussion}

\section{Remission rates}

A wide range of post-operative remission rates of $\mathrm{CD}$ (52-96.6\%) have been reported from different centres (3). The use of different definitions of remission criteria, in terms of time of post-surgical assessment and cut-offs of serum cortisol levels in various studies, might partly account for the reported variation in remission rates. The recent clinical practice guidelines have recommended the use of morning serum cortisol $<5 \mu \mathrm{g} / \mathrm{dL}$ (hypocortisolism) in first week post surgery to define early remission (7). Using this criterion, in the current study, we found an overall remission rate of $65.6 \%$, which falls within the range reported in literature. In our study, we found that $19.6 \%$ of the patients achieved delayed remission (eu- or hypocortisolism) in first 6 months post-surgery. The phenomenon of delayed remission is well recognised and reported to be 5.6-10\% across different centres $(15,16,17)$. Although the delayed remission rate observed in our study seems apparently higher than that reported in most other studies (5.6\% in the study by Valassi and coworkers (17), 7.7\% in the study by Pereira and coworkers (15)), we believe the variation in the definitions of early and delayed remissions used across studies might account for the observed differences. Valassi and coworkers (17) have grouped patients with post-operative eu- and hypocortisolism in the early remission group, while in our study, only hypocortisolemic patients constituted this group, thus making the denomination for the calculation of delayed remission rate different. Unlike our study criteria, Pereira and coworkers (15) reported delayed (at 3 months post-surgery) remission in 6/78 (7.7\%) patients using stricter criteria of serum cortisol $<1.8 \mu \mathrm{g} /$ dL. This observation emphasises the need for defining uniform criteria of delayed remission to be used across centres. Proposed hypotheses for delayed remission include late necrosis of residual pituitary tumour tissue, declining adrenal autonomy or cortisol cyclicity and need to be studied in future (17). http://www.endocrineconnections.org
DOI: 10.1530/EC-17-0175
(C) 2017 The authors Published by Bioscientifica Ltd
This work is licensed under a Creative Commons Attribution-NonCommercial 4.0 International License. 


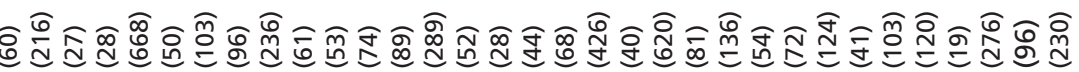

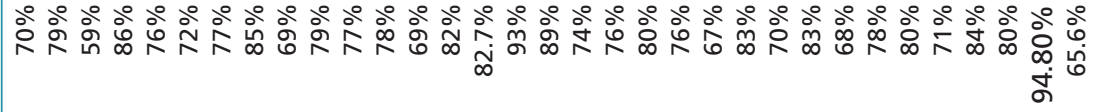

ำ

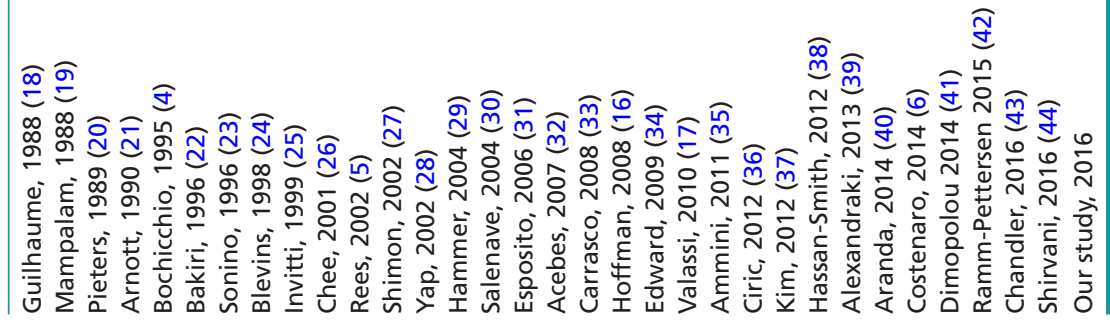

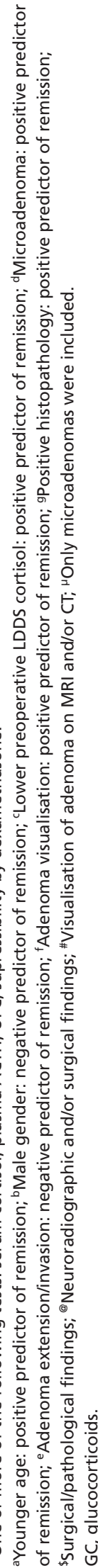

http://www.endocrineconnections.org DOI: 10.1530/EC-17-0175 (c) 2017 The authors Published by Bioscientifica Ltd

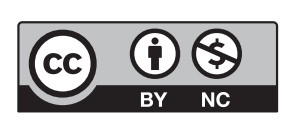

This work is licensed under a Creative Commons Attribution-NonCommercial 4.0 International Attribution 


\section{Predictors of remission}

Studying factors affecting remission is important to predict prognosis of patients undergoing TSS. Table 3 lists studies that have statistically analysed predictors for remission following primary microscopic TSS in CD (adult \pm paediatric) patients. Similar to that reported in most previous studies, in the current study, we found that none of the clinical or biochemical parameters had a predictive value for remission (Table 3 ).

Size of the adenoma (microadenoma vs macroadenoma) noted on neuroradiographic (MRI/CT) and/or surgical findings has been studied as a predictor for remission. As evident from Table 3, most of the studies reported macroadenoma to have similar or poorer outcomes as compared to microadenoma. Better surgical outcome for microadenoma observed in our study is in accordance with the recent meta-analysis (45), which reports significantly higher remission rates for patients with microadenoma than those with macroadenoma (83\% vs 63\%). Blevins and coworkers (24) proposed that this difference in remission rates may be due to varying tumoural biological behaviour (i.e. size and/or invasiveness). Poor remission rates for macroadenoma, especially for those with cavernous sinus invasion observed in our study group, further support this contention.

In our series, surgical results of patients with MRI-visible microadenoma were significantly better than those with IPSS-proven CD patients with negative/ equivocal MRI findings. Visualisation of pituitary adenoma on pre-surgical imaging has been reported to have a better outcome in various studies (including ours), while others achieved comparable results irrespective of adenoma visualisation (Table 3). Differing methodological factors across various studies like sensitivity of imaging modalities used (CT vs MRI), confirmation of central origin with IPSS, inclusion of macroadenoma patients in sub-analysis and extent of neurosurgery performed in the absence of visible adenoma might account for the varying outcome across studies $(4,18,25,26)$. Use of sensitive MRI techniques like VI-SGE sequences is expected to enhance adenoma detection rate and may result in better outcomes (12). However in MRI-negative/equivocal cases, optimal surgical strategy (extent of exploration and resection) still needs further research.

Histopathological confirmation of an adenoma has been reported as a predictor of better remission rates in most of the studies, while others, like our study, have found no differences in the outcome. Patients achieving remission despite negative histology can possibly be explained by in-situ necrosis and vascular damage of the adenoma following surgical exploration, loss of tissue in suction or tissue being missed on pathological sections (46).

\section{Recurrence and its predictors}

Overall recurrence rate (41\%) after first TSS in our study falls within the broad range (15-66\%) as reported in literature (7). As observed in our study, majority of the past studies $(6,37,50,52)$ have reported that baseline demographic, hormonal, neuroradiological and histopathological findings do not have a predictive value for recurrence. Amongst the various factors studied, postoperative cortisol dynamics seem to be a most important predictive factor for recurrence (Table 4).

Early remission vs delayed remission In our study, patients with delayed remission had higher recurrence rate than patients with early remission $(61.5 \%$ vs $30.8 \%$, $P=0.001)$. This finding is similar to that of Valassi and coworkers (17) who reported 43\% recurrence rate in patients with delayed remission as compared to $14 \%$ in the early remission group $(P=0.02)$. It can be speculated that the residual tumour cells undergoing gradual vascular insult (over weeks) that may be responsible for the phenomenon of delayed remission are more likely to recover later (over months to years) and account for observed higher recurrence rate.

\section{Degree of early post-operative}

hypocortisolism Complete removal of ACTH-secreting pituitary adenoma is expected to result in low-circulating ACTH and cortisol levels due to prolonged suppression of normal corticotrophs. Hence, achieving immediate postsurgical hypocortisolism has been recognised as the goal of successful TSS. Further parameters of post-operative hypocortisolism in terms of its degree and duration have been studied as predictors of recurrence (Table 4). In our study, we did not find degree of hypocortisolism to have a significant predictive value, but observed a trend towards lower recurrence rates in patients with early remission who have serum cortisol $<1.8 \mu \mathrm{g} / \mathrm{dL}$ vs those with $1.8-4.9 \mu \mathrm{g} / \mathrm{dL}$. While few of the earlier studies have reported significantly lower recurrence rates in patients with greater degree of hypocortisolism, they have used higher cut-off of $>5 \mu \mathrm{g} / \mathrm{dL}$ to define hypocortisolism

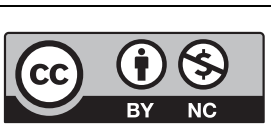

This work is licensed under a Creative Commons Attribution-NonCommercial 4.0 International License. 
Table 4 Summary of series reporting post-surgery cortisol dynamics as predictors of recurrence following primary microscopic TSS in CD.

\begin{tabular}{l}
\hline Study (First author, year) \\
\hline Tahir and Sheeler, 1992 (47) \\
Trainer, 1993 (8) \\
Viganti, 1994 (48) \\
Bochicchio, 1995 (4) \\
Invitti, 1999 (25) \\
Imaki, 2001 (49) \\
Pereira, 2003 (15) \\
Patil, 2008 (50) \\
Sughrue, 2011 (51) \\
Lindsay, 2011 (9) \\
Ciric, 2012 (36) \\
Alexandraki, 2013 (39) \\
Barbot, 2013 (52) \\
Costenaro, 2014 (6) \\
Dimopolou, 2014 (41) \\
Our study, 2016
\end{tabular}

\begin{tabular}{c} 
Recurrence rate $\%$ (No \\
of patients in remission/ \\
Total no of patients) \\
\hline $20.6 \%(34 / 34)$ \\
$12.5 \%(32 / 48))$ \\
$20 \%(30 / 36)$ \\
$12.7 \%(510 / 668)$ \\
$17 \%(162 / 236)$ \\
$13.3 \%(30 / 49)$ \\
$9 \%(56 / 80)$ \\
$17 \%(184 / 215)$ \\
$26 \%(73 / 88)$ \\
$12 \%(325 / 450)$ \\
$9.67 \%(101 / 121)$ \\
$24 \%(84 / 124)$ \\
$38.5 \%(39 / 57)$ \\
$8 \%(81 / 101)$ \\
$34 \%(85 / 120)$ \\
$41.02 \%(151 / 230)$
\end{tabular}

\begin{tabular}{c}
\hline $\begin{array}{l}\text { Degree of early post-surgery } \\
\text { hypocortisolemia }\end{array}$ \\
- \\
$Y^{*, a}$ \\
- \\
- \\
$N^{\#}$ \\
$Y^{*, a}$ \\
$N^{\#}$ \\
$Y^{* *, a}$ \\
$Y^{*, a}$ \\
$N^{\#}$ \\
$N^{\#}$ \\
- \\
- \\
- \\
- \\
$N^{\#}$
\end{tabular}

\begin{tabular}{c}
\hline $\begin{array}{c}\text { Duration of } \\
\text { hypocortisolemia }\end{array}$ \\
\hline $\mathrm{N}$ (need for GC) \\
- \\
- \\
$\mathrm{Y}$ (need for GC) \\
- \\
- \\
- \\
- \\
- \\
- \\
- \\
$Y^{\mathrm{b}}$ \\
- \\
$\mathrm{N}($ need for GC) \\
$N$ \\
$Y$
\end{tabular}

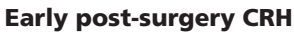
stimulation test

Predictor of recurrence: $Y$ (yes); N (no)

${ }^{a}$ Higher degree of early post-operative hypocortisolemia: positive predictor for long-term remission; bonger duration of hypocortisolemia: positive predictor for long-term remission; 'Lower CRH-stimulated cortisol and/or ACTH in early post-operative period: positive predictor for long-term remission; *Cut-off of serum cortisol used to define hypocortisolism was above $5 \mu \mathrm{g} / \mathrm{dL}$; ${ }^{*}$ Cut-off of serum cortisol used to define hypocortisolism was $5 \mu \mathrm{g} / \mathrm{dL}$, but also included patients with normal urinary-free cortisol; "Cut-off of serum cortisol used to define hypocortisolism was $\leq 5 \mu \mathrm{g} / \mathrm{dL}$.

$(8,49,51)$. However, more recent studies using cut-off of $<5 \mu \mathrm{g} / \mathrm{dL}$ to define hypocortisolism (similar to cut-off in the current study) have reported no significant difference in recurrence rates in patients with serum cortisol nadir $<2 \mu \mathrm{g} / \mathrm{dL}$ vs $2-4.9 \mu \mathrm{g} / \mathrm{dL}$, which is similar to our findings $(9,15,25,36)$.

One of the limitations of our study is the absence of data on post-operative stimulation tests (CRH, desmopressin) as these tests were not routinely performed. Nevertheless, these stimulation tests in the early post-operative period have not been shown to have any additional benefit in predicting long-term remission status over that of early post-operative basal cortisol levels (7).

\section{Duration of post-operative hypocortisolism} Unlike degree of post-operative hypocortisolism, its duration remains an under acknowledged predictor of long-term remission. Earliest indication of its predictive value was given in 1979 by Pont and coworkers (53), who speculated that the need for early withdrawal of steroid replacement therapy could be a clue to disease recurrence. Later, Bochicchio and coworkers (4) have reported that $97 \%$ of the patients requiring glucocorticoid replacement therapy for more than one year duration had sustained remission at mean follow-up of 5 years. In the current study, we found longer duration of post-operative hypocortisolism DOI: 10.1530/EC-17-0175 to be a positive predictor of sustained remission with a duration $\geq 13$ months, predicting remission with $100 \%$ specificity (at sensitivity of $46.4 \%$ ) over a mean follow-up of 74 months. In a similar study, Alexandriki and coworkers (39) reported that the absence of HPA axis recovery within 12 months post-surgery predicted sustained remission with specificity of $89.1 \%$ (at sensitivity of $64.7 \%$ ). In contrast to these studies, Dimopoulou and coworkers (41) did not find a significant difference in the mean duration of hypocortisolemia in patients with and without disease recurrence (32 months vs 48 months). Differences in definitions of recovery of adrenocortical function (normal response to ACTH stimulation test) and disease recurrence (elevated 24-h UFC/LDDS cortisol $\geq 5 \mu \mathrm{g} / \mathrm{dL}$ ) used at their centre might have accounted for different results (54). Biologically, it can be speculated that shorter duration of hypocortisolism may be a manifestation of early recovery of autonomy of residual tumour cells, while longer duration of hypocortisolism represents later occurrence of CRH-stimulated recovery of normal corticotrophs and hence a predictor of long-term remission.

Time to recurrence In their retrospective analysis, Bochichio and coworkers (4) have observed no apparent plateau or clustering in the distribution of recurrences in $510 \mathrm{CD}$ patients over a follow-up period of 10 years.

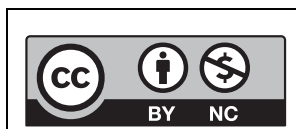

This work is licensed under a Creative Commons Attribution-NonCommercial 4.0 International License. 
Although we found a plateauing of recurrence on a longer follow-up period of 22.5 years, our finding of constant decrease in recurrence-free survival rates without apparent clustering in the initial 8 years was similar to that of Bochichio and coworkers (4). This emphasises the impact of duration of follow-up in studying time to recurrence. The extent of evaluation on follow-up visits (clinical vs biochemical) is another important consideration in studying time to recurrence. We observed an early identification of recurrence (at a mean time to recurrence of 27.7 months) and earlier plateauing of recurrence-free survival curve at 5 years in a sub-group of patients where serial data on biochemical evaluation (ODST) were available, as compared to that of patients with irregular and infrequent followup (mean time to recurrence of 69.2 months). Thus, our findings emphasise the importance of regular biochemical surveillance of patients in remission to detect recurrence before the disease becomes clinically obvious, thus allowing for timely intervention. Several biochemical tests like midnight serum/salivary cortisol, ODST and 24-h urinaryfree cortisol are used to detect disease recurrence. In two longitudinal studies, midnight serum and salivary cortisol have been shown to be the earliest sign of recurrence and almost always precede elevated urine cortisol (7). However, serial data comparing sensitivity of midnight serum or salivary cortisol vs ODST to identify early disease recurrence are lacking. One of the limitations of the current study is that recurrence was defined based on ODST values alone, making its comparison with other tests impossible.

Site of recurrence An interesting observation in our study was visualisation of adenoma at the same sellar location (as baseline scan), in all patients (micro/ macro adenomas) with equivocal adenoma seen on the MRI scan at the time of recurrence. Our observation is substantiated by few of the previous surgical series $(55,56$, 57 ) where intra-operative findings at subsequent surgeries for recurrent $\mathrm{CD}$ have been described. In a large series of patients who underwent surgery for recurrent CD, Dickerman and coworkers (57) reported that recurrent tumour was found at the same site or contiguous to the same site as the initial surgery. Additionally at repeat surgery, adenomatous invasion of the dura mater was found in 54\% and $100 \%$ of microadenomas and macroadenomas, respectively. Thus, it can be inferred that recurrent $\mathrm{CD}$ could result from regrowth of the residual tissue at the primary site or adjacent dura mater.
Retrospective nature of the study with its attendant data attrition forms the major limitation of our study. However, long-term follow-up of respectable number of CD patients at a single centre, thus conforming uniformity in work-up and management of entire cohort, represents the strengths of the study. Moreover, determination of remission/recurrence by biochemical evaluation, rather than self-reported clinical information, has ensured objectivity in the analysis.

\section{Conclusion}

We report long-term post-surgical follow-up of $230 \mathrm{CD}$ patients managed at a single centre. Overall, remission and recurrence rates were similar to that reported in literature, but proportion of delayed remission was relatively higher. Radiological features like negative/equivocal MRI findings and presence of macroadenoma, especially those with cavernous sinus invasion, were predictors of poor remission rates. In addition to early remission, longer duration of post-operative hypocortisolism is an important predictor of sustained remission. Regular biochemical surveillance may help in identifying recurrence early.

\section{Declaration of interest}

The authors declare that there is no conflict of interest that could be perceived as prejudicing the impartiality of the research reported.

\section{Funding}

This work did not receive any specific grant from any funding agency in the public, commercial or not-for-profit sector.

\section{References}

1 Arnardóttir S \& Sigurjonsdóttir HA. The incidence and prevalence of Cushing's disease may be higher than previously thought: results from a retrospective study in Iceland 1955 through 2009. Clinical Endocrinology 201174 792-793. (doi:10.1111/j.13652265.2010.03961.x)

2 Clayton RN, Raskauskiene D, Reulen RC \& Jones PW. Mortality and morbidity in Cushing's disease over 50 years in Stoke-on-Trent, UK: audit and meta-analysis of literature. Journal of Clinical Endocrinology and Metabolism 201096 632-642. (doi:10.1210/jc.2010-1942)

3 Petersenn S, Beckers A, Ferone D, Van Der Lely A, Bollerslev J, Boscaro M, Brue T, Bruzzi P, Casanueva FF, Chanson P, et al. Therapy of endocrine disease: outcomes in patients with Cushing's disease undergoing transsphenoidal surgery: systematic review assessing criteria used to define remission and recurrence. European Journal of Endocrinology 2015172 R227-R239. (doi:10.1530/EJE-14-0883)

4 Bochicchio DO, Losa M \& Buchfelder MI. Factors influencing the immediate and late outcome of Cushing's disease treated by transsphenoidal surgery: a retrospective study by the European 
Cushing's disease survey group. Journal of Clinical Endocrinology and Metabolism 199580 3114-3120. (doi:10.1210/jcem.80.11.7593411)

5 Rees DA, Hanna FW, Davies JS, Mills RG, Vafidis J \& Scanlon MF. Long-term follow-up results of transsphenoidal surgery for Cushing's disease in a single centre using strict criteria for remission. Clinical Endocrinology 200256 541-551. (doi:10.1046/j.13652265.2002.01511.x)

6 Costenaro F, Rodrigues TC, Rollin GA, Ferreira NP \& Czepielewski MA. Evaluation of Cushing's disease remission after transsphenoidal surgery based on early serum cortisol dynamics. Clinical Endocrinology 201480 411-418. (doi:10.1111/cen.12300)

7 Nieman LK, Biller BM, Findling JW, Murad MH, Newell-Price J, Savage MO \& Tabarin A. Treatment of Cushing's syndrome: an endocrine society clinical practice guideline. Journal of Clinical Endocrinology and Metabolism 2015100 2807-2831. (doi:10.1210/ jc.2015-1818)

8 Trainer PJ, Lawrie HS, Verhelst J, Howlett TA, Lowe DG, Grossman AB, Savage MO, Afshar F \& Besser GM. Transsphenoidal resection in Cushing's disease: undetectable serum cortisol as the definition of successfuI treatment. Clinical Endocrinology $1993 \mathbf{3 8}$ 73-78. (doi:10.1111/j.1365-2265.1993.tb00975.x)

9 Lindsay JR, Oldfield EH, Stratakis CA \& Nieman LK. The postoperative basal cortisol and CRH tests for prediction of long-term remission from Cushing's disease after transsphenoidal surgery. Journal of Clinical Endocrinology and Metabolism 201196 2057-2064. (doi:10.1210/jc.2011-0456)

10 Losa M, Mortini P, Dylgjeri S, Barzaghi R, Franzin A, Mandelli C \& Giovanelli M. Desmopressin stimulation test before and after pituitary surgery in patients with Cushing's disease. Clinical Endocrinology 200155 61-68. (doi:10.1046/j.13652265.2001.01324.x)

11 Nieman LK, Biller BM, Findling JW, Newell-Price J, Savage MO, Stewart PM \& Montori VM. The diagnosis of Cushing's syndrome: an endocrine society clinical practice guideline. Journal of Clinical Endocrinology and Metabolism 200893 1526-1540. (doi:10.1210/ jc.2008-0125)

12 Kasaliwal R, Sankhe SS, Lila AR, Budyal SR, Jagtap VS, Sarathi V, Kakade H, Bandgar T, Menon PS \& Shah NS. Volume interpolated 3D-spoiled gradient echo sequence is better than dynamic contrast spin echo sequence for MRI detection of corticotropin secreting pituitary microadenomas. Clinical Endocrinology 201378 825-830. (doi:10.1111/cen.12069)

13 Newell-Price J, Bertagna X, Grossman AB \& Nieman LK. Cushing's syndrome. Lancet 2006367 1605-1617. (doi:10.1016/S01406736(06)68699-6)

14 Knosp E, Steiner E, Kitz K \& Matula C. Pituitary adenomas with invasion of the cavernous sinus space: a magnetic resonance imaging classification compared with surgical findings. Neurosurgery 199333 610-618. (doi:10.1227/00006123-199310000-00008)

15 Pereira AM, van Aken MO, van Dulken H, Schutte PJ, Biermasz NR, Smit JW, Roelfsema F \& Romijn JA. Long-term predictive value of postsurgical cortisol concentrations for cure and risk of recurrence in Cushing's disease. Journal of Clinical Endocrinology and Metabolism 200388 5858-5864. (doi:10.1210/jc.2003-030751)

16 Hofmann BM, Hlavac M, Martinez R, Buchfelder M, Müller OA $\&$ Fahlbusch R. Long-term results after microsurgery for Cushing disease: experience with 426 primary operations over 35 years. Journal of Neurosurgery 2008 108 9-18. (doi:10.3171/ JNS/2008/108/01/0009)

17 Valassi E, Biller BM, Swearingen B, Pecori Giraldi F, Losa M, Mortini P, Hayden D, Cavagnini F \& Klibanski A. Delayed remission after transsphenoidal surgery in patients with Cushing's disease. Journal of Clinical Endocrinology and Metabolism 201095 601-610. (doi:10.1210/ jc.2009-1672)

18 Guilhaume B, Bertagna X, Thomsen M, Bricaire C, Vila-Porcile Ev, Olivier L, Racadot J, Derome P, Laudat Mh, Girard F, et al.
Transsphenoidal pituitary surgery for the treatment of Cushing's disease: results in 64 patients and long term follow-up studies. Journal of Clinical Endocrinology and Metabolism 198866 1056-1064. (doi:10.1210/jcem-66-5-1056)

19 Mampalam TJ, Tyrrell JB \& Wilson CB. Transsphenoidal microsurgery for Cushing disease: a report of 216 cases. Annals of Internal Medicine 1988109 487-493. (doi:10.7326/0003-4819-109-6-487)

20 Pieters GF, Hermus AR, Meijer E, Smals AG \& Kloppenborg PW. Predictive factors for initial cure and relapse rate after pituitary surgery for Cushing's disease. Journal of Clinical Endocrinology and Metabolism 198969 1122-1126. (doi:10.1210/jcem-69-6-1122)

21 Arnott RD, Pestell RG, McKelvie PA, Henderson JK, McNeill PM \& Alford FP. A critical evaluation of transsphenoidal pituitary surgery in the treatment of Cushing's disease: prediction of outcome. Acta Endocrinologica 1990123 423-430. (doi:10.1530/acta.0.1230423)

22 Bakiri F, Tatai S, Aouali R, Semrouni M, Derome P, Chitour F \& Benmiloud M. Treatment of Cushing's disease by transsphenoidal, pituitary microsurgery: prognosis factors and long-term follow-up. Journal of Endocrinological Investigation 199619 572-580. (doi:10.1007/BF03349020)

23 Sonino NI, Zielezny MA, Fava GA, Fallo F \& Boscaro M. Risk factors and long-term outcome in pituitary-dependent Cushing's disease. Journal of Clinical Endocrinology and Metabolism 199681 2647-2652. (doi:10.1210/jcem.81.7.8675592)

24 Blevins LS Jr, Christy JH, Khajavi M \& Tindall GT. Outcomes of therapy for Cushing's disease due to adrenocorticotropin-secreting pituitary macroadenomas. Journal of Clinical Endocrinology and Metabolism 199883 63-67. (doi:10.1210/jcem.83.1.4525)

25 Invitti C, Giraldi FP, De Martin M \& Cavagnini F. Diagnosis and management of Cushing's syndrome: results of an italian multicentre study. Journal of Clinical Endocrinology and Metabolism $19998 \mathbf{8 4}$ 440-448. (doi:10.1210/jcem.84.2.5465)

26 Chee GH, Mathias DB, James RA \& Kendall-Taylor P. Transsphenoidal pituitary surgery in Cushing's disease: can we predict outcome? Clinical Endocrinology 200154 617-626. (doi:10.1046/j.13652265.2001.01261.x)

27 Shimon I, Ram Z, Cohen ZR \& Hadani M. Transsphenoidal surgery for Cushing's disease: endocrinological follow-up monitoring of 82 patients. Neurosurgery 200251 57-62. (doi:10.1097/00006123200207000-00008)

28 Yap LB, Turner HE, Adams CB \& Wass JA. Undetectable postoperative cortisol does not always predict long-term remission in Cushing's disease: a single centre audit. Clinical Endocrinology 200256 25-31. (doi:10.1046/j.0300-0664.2001.01444.x)

29 Hammer GD, Tyrrell JB, Lamborn KR, Applebury CB, Hannegan ET, Bell S, Rahl R, Lu A \& Wilson CB. Transsphenoidal microsurgery for Cushing's disease: initial outcome and long-term results. Journal of Clinical Endocrinology and Metabolism 200489 6348-6357. (doi:10.1210/jc.2003-032180)

30 Salenave S, Gatta B, Pecheur S, San-Galli F, Visot A, Lasjaunias P, Roger P, Berge J, Young J, Tabarin A, et al. Pituitary magnetic resonance imaging findings do not influence surgical outcome in adrenocorticotropin-secreting microadenomas. Journal of Clinical Endocrinology and Metabolism 200489 3371-3376. (doi:10.1210/ jc.2003-031908)

31 Esposito F, Dusick JR, Cohan P, Moftakhar P, McArthur D, Wang C, Swerdloff RS \& Kelly DF. Early morning cortisol levels as a predictor of remission after transsphenoidal surgery for Cushing's disease. Journal of Clinical Endocrinology and Metabolism 2006 91 7-13. (doi:10.1210/jc.2005-1204)

32 Acebes JJ, Martino J, Masuet C, Montanya E \& Soler J. Early postoperative ACTH and cortisol as predictors of remission in Cushing's disease. Acta Neurochirurgica 2007149 471-479. (doi:10.1007/s00701007-1133-1)

33 Carrasco CA, Coste J, Guignat L, Groussin L, Dugué MA, Gaillard S, Bertagna X \& Bertherat J. Midnight salivary cortisol determination http://www.endocrineconnections.org

DOI: 10.1530/EC-17-0175

(C) 2017 The authors

Published by Bioscientifica Ltd
This work is licensed under a Creative Commons Attribution-NonCommercial 4.0 International License. 
for assessing the outcome of transsphenoidal surgery in Cushing's disease. Journal of Clinical Endocrinology and Metabolism 200893 4728-4734. (doi:10.1210/jc.2008-1171)

34 Fomekong E, Maiter D, Grandin C \& Raftopoulos C. Outcome of transsphenoidal surgery for Cushing's disease: a high remission rate in ACTH-secreting macroadenomas. Clinical Neurology and Neurosurgery 2009111 442-449. (doi:10.1016/j.clineuro.2008.12.011)

35 Ammini AC, Bhattacharya S, Sahoo JP, Philip J, Tandon N, Goswami R, Jyotsna VJ, Khadgawat R, Chumber S, Seth A, et al. Cushing's disease: results of treatment and factors affecting outcome. Hormones 201110 222-229. (doi:10.14310/horm.2002.1312)

36 Ciric I, Zhao JC, Du H, Findling JW, Molitch ME, Weiss RE, Refetoff S, Kerr WD \& Meyer J. Transsphenoidal surgery for Cushing disease: experience with 136 patients. Neurosurgery 201270 70-81. (doi:10.1227/NEU.0b013e31822dda2c)

37 Kim JH, Shin CS, Paek SH, Jung HW, Kim SW \& Kim SY. Recurrence of Cushing's disease after primary transsphenoidal surgery in a university hospital in Korea. Endocrine Journal 201259 881-888. (doi:10.1507/endocrj.EJ12-0109)

38 Hassan-Smith ZK, Sherlock M, Reulen RC, Arlt W, Ayuk J, Toogood AA, Cooper MS, Johnson AP \& Stewart PM. Outcome of Cushing's disease following transsphenoidal surgery in a single center over 20 years. Journal of Clinical Endocrinology and Metabolism 201297 1194-1201. (doi:10.1210/jc.2011-2957)

39 Alexandraki KI, Kaltsas GA, Isidori AM, Storr HL, Afshar F, Sabin I, Akker SA, Chew SL, Drake WM, Monson JP, et al. Long-term remission and recurrence rates in Cushing's disease: predictive factors in a single-centre study. European Journal of Endocrinology 2013168 639-648. (doi:10.1530/EJE-12-0921)

40 Aranda G, Ensenat J, Mora M, Puig-Domingo M, De Osaba MM, Casals G, Verger E, Ribalta MT, Hanzu FA \& Halperin I. Long-term remission and recurrence rate in a cohort of Cushing's disease: the need for long-term follow-up. Pituitary 201518 142-149. (doi:10.1007/s11102-014-0567-8)

41 Dimopoulou C, Schopohl J, Rachinger W, Buchfelder M, Honegger J, Reincke M \& Stalla GK. Long-term remission and recurrence rates after first and second transsphenoidal surgery for Cushing's disease: care reality in the Munich metropolitan region. European Journal of Endocrinology 2014170 283-292. (doi:10.1530/EJE-13-0634)

42 Ramm-Pettersen J, Halvorsen H, Evang JA, Rønning P, Hol PK, Bollerslev J, Berg-Johnsen J \& Helseth E. Low immediate postoperative serum-cortisol nadir predicts the short-term, but not long-term, remission after pituitary surgery for Cushing's disease. BMC Endocrine Disorders 201515 62. (doi:10.1186/s12902-015-0055-9)

43 Chandler WF, Barkan AL, Hollon T, Sakharova A, Sack J, Brahma B $\&$ Schteingart DE. Outcome of transsphenoidal surgery for cushing disease: a single-center experience over 32 years. Neurosurgery 2016 78 216-223. (doi:10.1227/NEU.0000000000001011)

44 Shirvani M, Motiei-Langroudi R \& Sadeghian H. Outcome of microscopic transsphenoidal surgery in Cushing disease: a case series of 96 patients. World Neurosurgery 201687 170-175. (doi:10.1016/j. wneu.2015.11.046)

45 Dabrh AM, Singh Ospina NM, Nofal AA, Farah WH, Barrionuevo P, Sarigianni M, Mohabbat AB, Benkhadra K, Carranza Leon BG,
Gionfriddo MR, et al. Predictors of biochemical remission and recurrence after surgical and radiation treatments of Cushing disease: a systematic review and meta-analysis. Endocrine Practice 201622 466-475. (doi:10.4158/EP15922.RA)

46 Pouratian N, Prevedello DM, Jagannathan J, Lopes MB, Vance ML \& Laws ER Jr. Outcomes and management of patients with Cushing's disease without pathological confirmation of tumor resection after transsphenoidal surgery. Journal of Clinical Endocrinology and Metabolism 200792 3383-3388. (doi:10.1210/ jc.2007-0208)

47 Tahir AH \& Sheeler LR. Recurrent Cushing's disease after transsphenoidal surgery. Archives of Internal Medicine 1992152 977-981. (doi:10.1001/archinte.1992.00400170067013)

48 Vignati F, Berselli ME \& Loli P. Early postoperative evaluation in patients with Cushing's disease: usefulness of ovine corticotropinreleasing hormone test in the prediction of recurrence of disease. European Journal of Endocrinology 1994130 235-241. (doi:10.1530/ eje.0.1300235)

49 Imaki T, Tsushima T, Hizuka N, Odagiri E, Murata Y, Suda T \& Takano K. Postoperative plasma cortisol levels predict long-term outcome in patients with Cushing's disease and determine which patients should be treated with pituitary irradiation after surgery. Endocrine Journal 200148 53-62. (doi:10.1507/endocrj.48.53)

50 Patil CG, Prevedello DM, Lad SP, Vance ML, Thorner MO, Katznelson L \& Laws ER Jr. Late recurrences of Cushing's disease after initial successful transsphenoidal surgery. Journal of Clinical Endocrinology and Metabolism 200893 358-362. (doi:10.1210/jc.2007-2013)

51 Sughrue ME, Shah JK, Devin JK, Kunwar S \& Blevins LS Jr. Utility of the immediate postoperative cortisol concentrations in patients with Cushing's disease. Neurosurgery 201067 688-695. (doi:10.1227/01. NEU.0000374722.50042.FF)

52 Barbot M, Albiger N, Koutroumpi S, Ceccato F, Frigo AC, Manara R, Fassina A, Gardiman MP, Scanarini M, Mantero F, et al. Predicting late recurrence in surgically treated patients with Cushing's disease. Clinical Endocrinology 201379 394-401. (doi:10.1111/cen.12133)

53 Pont A \& Gutierrez-Hartman A. Cushing's disease: recurrence after a surgically induced remission. Archives of Internal Medicine 1979139 938-940. (doi:10.1001/archinte.1979.03630450080027)

54 Berr CM, Di Dalmazi G, Osswald A, Ritzel K, Bidlingmaier M, Geyer LL, Treitl M, Hallfeldt K, Rachinger W, Reisch N, et al. Time to recovery of adrenal function after curative surgery for Cushing's syndrome depends on etiology. Journal of Clinical Endocrinology and Metabolism 2014100 1300-1308. (doi:10.1210/jc.2014-3632)

55 Nakane T, Kuwayama A, Watanabe M, Takahashi T, Kato T, Ichihara K $\&$ Kageyama N. Long term results of transsphenoidal adenomectomy in patients with Cushing's disease. Neurosurgery 198721 218-222. (doi:10.1227/00006123-198708000-00015)

56 Lüdecke DK, Heinrichs M \& Saeger W. Recurrences after transnasal adenomectomy in Cushing's disease. In Pitruitary Adenomas: New Trends in Basic and Clinical Research, pp 329-336. Amsterdam, Netherlands: Excerpta Medica, 1991.

57 Dickerman RD \& Oldfield EH. Basis of persistent and recurrent Cushing disease: an analysis of findings at repeated pituitary surgery. Journal of Neurosurgery 200297 1343-1349. (doi:10.3171/jns.2002.97.6.1343)
Received in final form 8 September 2017

Accepted 14 September 2017

Accepted Preprint published online 14 September 2017 http://www.endocrineconnections.org
DOI: 10.1530/EC-17-0175
(C) 2017 The authors Published by Bioscientifica Ltd

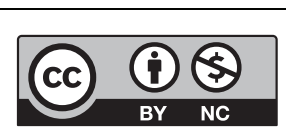

This work is licensed under a Creative Commons Attribution-NonCommercial 4.0 International License. 